\title{
DIE AARD VAN WETGEWENDE DISKRESIES BY DIE SUID-AFRIKAANSE UITVOERENDE GESAG
}

\section{$1 \quad$ Inleiding}

In enige moderne demokrasie is daar een of ander vorm van skeiding van magte tussen die wetgewende, uitvoerende en regsprekende gesag. Hierdie skeiding van magte, die sogenaamde trias politica, kan sover teruggevoer word as 1215, met die ondertekening van die Magna Carta deur Koning John van Engeland. Deur die eeue het hierdie skeiding van magte verskillende vorme aangeneem en is dit met die kolonialisering van die Nuwe Wêreld ook na ander dele van die aardbol uitgedra, sodat dit in 1789 gelei het tot die aanvaarding van die Amerikaanse grondwet soos wat ons dit vandag nog ken. ${ }^{1}$ Meer as tweehonderd jaar later is dit steeds die standvastigste van hierdie soort dokumente aan ons bekend en versinnebeeld dit vir baie die idee van vryheid en gelykheid wat deur die idee van die skeiding van magte verskans word.

In Suid-Afrika is daar ook na Uniewording in 1910 die idee van die skeiding van magte volgens die Westminster-model nagestreef. ${ }^{2}$ Dit het egter ongetwyfeld tot 'n mindere mate geskied as vandag waar ons nog steeds streef om die idee van 'n regstaat te laat realiseer. Gevolglik is die vraagstuk wat in hierdie artikel aangespreek sal word die kwessie aangaande wetgewende diskresies wat by die uitvoerende gesag berus en sal daar gepoog word om 'n antwoord te verskaf op die vraag wat handel oor hoeveel wetgewende gesag wel by die uitvoerende gesag berus (en kan berus). Aan die einde van die negentiende eeu het die Amerikaanse Supreme Court ten opsigte van die skeiding van magte die houding ingeneem dat:

1 Devenish Commentary 41213108.

2 Rautenbach en Malherbe Staatsreg 73. 
Each branch must be limited to the exercise of the powers appropriate to its own department and no other. ${ }^{3}$

Hierdie standpunt word tans as 'n onverdedigbare ekstreem beskou ten opsigte van die leerstuk van die skeiding van magte. ${ }^{4}$ Hierdie laasgenoemde siening is ook so deur die Suid-Afrikaanse Konstitusionele Hof bevestig in die eerste sertifiseringsuitspraak waarin dit gestel is dat geen volkome skeiding van magte moontlik is nie. 'n Skeiding van magte is altyd gedeeltelik. ${ }^{5}$ Een van die hoofredes hiervoor is die feit dat die verlening van (wetgewende) diskresies deur die wetgewer noodsaaklik is vir die bestuur van die moderne staat. ${ }^{6}$ Daar word vereis dat wetgewende gesag, soos gesetel in die Parlement, na die uitvoerende gesag gedelegeer word. Dit word gedoen by wyse van magtigende wetgewing wat die raamwerk moet verskaf waarbinne die gedelegeerde gesag uitgeoefen kan word. ${ }^{7}$

Omdat dit dus vir die wetgewer onmoontlik is om alle denkbare toekomstige feitekomplekse te reël, word dit aan die administrasie oorgelaat - deur middel van die diskresie-inruiming - om hom so by die gegewe omstandighede aan te pas dat, by die behandeling van 'n bepaalde aangeleentheid, 'n oplossing gevind sal word wat sowel vir daardie enkele geval asook vir die algemene belang bevredigend en regverdig sal wees. ${ }^{8}$

Die volgende vraag moet ook beantwoord word: Indien die wetgewende gesag van die Republiek by die Parlement berus en die uitvoerende gesag by die President en die ander lede van die Kabinet, ${ }^{9}$ terwyl die uitvoerende gesag ook wetgewende bevoegdhede het, hoe wyd strek hierdie wetgewende bevoegdhede van die uitvoerende gesag dan? Die

$3 \quad$ Kilbourn v Thompson 103 US 168191 (1881) en Kendall v United States ex rel. Stokes 37 US (12 Pet) 524 (1838).

4 Tribe American Law 19.

5 In re: Certification of the Constitution of the Republic of South Africa 1996199610 BCLR 1253 (KH) par 109.

$6 \quad$ Hewitt Delegated Legislation 5-7.

7 Rabie en Erasmus 1989 SALJ 440.

8 Henning Diskresie in Administratiefreg 106-107. Sien ook Rautenbach en Malherbe Staatsreg 205 en Baxter Administrative Law 84. 
Parlement sou tog nie al sy wetgewende bevoegdhede aan die uitvoerende gesag kon oordra nie, want dan sal die skeiding van magte tussen die uitvoerende en wetgewende gesag verlore raak. Reeds in 1912 is die gevaar van wye diskresionêre bevoegdhede reeds deur waarnemende hoofregter Innes raakgesien toe hy opgemerk het:

There is a growing tendency in modern legislation to clothe with finality the decisions of public officials in matters which seriously affect the rights of the public, a tendency probably due to the increasing power of Departmental Officials (auguring) .... a serious menace to the liberty of the subject. $^{10}$

Met inagneming van hierdie kwessies en die feit dat die skeiding van magte in die SuidAfrikaanse reg reeds baie lank aandag geniet, sal hierdie argument hoofsaaklik op wetgewende diskresies toegespits wees. Dit handel dus oor hoeveel diskresionêre wetgewende gesag die uitvoerende gesag kan hê en die aard daarvan. ${ }^{11}$

\section{Ontleding van die begrip "wetgewende diskresie"}

Dit is belangrik om te besef wat die begrip "wetgewende diskresie" inhou, voordat daar enigsins met 'n bespreking van die probleem voorhande, voortgegaan kan word.

Keir en Lawson het reeds in 1954 die diskresie beskryf as: "a working compromise between the extremes of rigid legalism and unrestricted absolutism." ${ }^{12}$ Collins $^{13}$ definieer die begrip soos volg: "freedom or authority to make judgments and to act as one

$9 \quad$ A 85(1) en (2) van die Grondwet van die Republiek van Suid-Afrika 108 van 1996.

10 Shidiack v Union Government (Minister of the Interior) 1912 AD 642 653-654.

11 Daar moet daarop gelet word dat daar nie in hierdie bespreking gekyk sal word na die kwessie van die sogenaamde wetgewende inter-delegasie, maw die delegasie van gesag tussen die nasionale en provinsiale wetgewers of administratiewe inter-delegasie waar administratiewe amptenare of instellings hul gesag aan ander administratiewe amptenare of instellings delegeer nie. Daar sal slegs gefokus word op delegasie vanaf die wetgewende gesag na die uitvoerende gesag.

12 Keir en Lawson Constitutional Law in Henning Diskresie in Administratiefreg 107.

13 Makins English Dictionary 449. 
sees fit," terwyl die definisie van die Oxford Advanced Learner's Dictionary ${ }^{14}$ bykans dieselfde is: "the freedom to decide for oneself what should be done." Die definisie wat Oxford daarenteen aan die term "legislative" heg, is: "involved with or concerning the making of laws," ${ }^{15}$ en Collins omskryf dit as:

... of or relating to legislation; having the power or function of legislating;

of or relating to a legislature. ${ }^{16}$

'n Afrikaanse woordeboekdefinisie, wat ter sprake kom, is dié van die Handwoordeboek van die Afrikaanse Taal ${ }^{17}$ wat die term "diskresie" omskryf as:

Persoonlike oordeel; vryheid om te kies, beslissings te neem en op te tree volgens eie oordeel; goeddunke, vryheid van handeling. ${ }^{18}$

Dieselfde woordeboek definieer weer die term "wetgewend" as 'n byvoeglike naamwoord wat verband hou met die gesag om wette te kan maak. ${ }^{19}$ Hierteenoor word die begrip "diskresie" deur Hiemstra en Gonin omskryf as:

...'n oordeel wat nie aan vaste reëls, instruksies vooraf of kontrole agterna onderworpe is nie. ${ }^{20}$

In hierdie artikel sal daar na die begrip "wetgewende diskresie" verwys word as 'n kompetensie om wetgewende maatreëls te kan tref.

\section{Die Duitse regsposisie}

14 Crowther en Hornby Current English 330.

15 Crowther en Hornby Current English 674.

16 Makins English Dictionary 889.

17 Odendal ea Handwoordeboek 152-153.

18 Odendal ea Handwoordeboek 152-153.

19 Odendal ea Handwoordeboek 1279.

20 Hiemstra en Gonin Regswoordeboek 40. 


\subsection{Algemeen}

Ten opsigte van buitelandse reg is die posisie dat dit by die uitleg van die handves van regte in die Grondwet wel in ag geneem kan word ingevolge artikel 39(1)(c), maar dat dit nie dwingend is soos in die geval van die volkereg nie. Reeds in die sogenaamde inougurele uitspraak van die Konstitusionele hof, $S v$ Makwanyane, ${ }^{21}$ is daar verwys na buitelandse reg ten opsigte van die doodstrafkwessie en in verskeie daaropvolgende sake is daar dikwels van buitelandse reg gebruik gemaak. Dit moet egter beklemtoon word dat hierdie reg nie deurslaggewend is in ons reg, soos die geval is ten opsigte van die volkereg nie, weens die woordverskil tussen kan en moet in subartikels (b) en (c) van subartikel 39(1). ${ }^{22}$ Dit is 'n voldonge feit dat buitelandse reg egter wel aan die howe leiding verskaf oor die uitleg van soortgelyke kwessies in ander regstelsels. Gevolglik sal daar ook in hierdie bespreking na die posisie in ander regstelsels verwys word.

\subsection{Die posisie in Duitsland}

In die Duitse reg het die uitvoerende gesag geen oorspronklike wetgewende kompetensies nie. $^{23}$ Dit kan slegs daardie wetgewende kompetensies uitoefen wat spesifiek daaraan gedelegeer word deur die wetgewer of wat daaraan gegee word vir 'n baie beperkte doel en as 'n oorgangsmaatreël ${ }^{24}$ ingevolge die Duitse grondwet. ${ }^{25}$ Tesame hiermee bevat die Grundgesetz, anders as ons eie Grondwet, in artikel 80 daarvan, bepalings wat spesifiek handel met ondergeskikte wetgewing:

Article 80 (Issue of ordinances having force of law)

$21 S$ v Makwanyane 19956 BCLR 665 (KH).

22 39(1) When interpreting the Bill of Rights, a court, tribunal or forum -

(a) $\ldots$

(b) must consider international law; and

(c) may consider foreign law.

23 Singh German Administrative Law 19.

24 A 119 van die Grundgesetz für die Bundesrepublik Deutschland magtig die Federale Regering om met toestemming van die Bundesrat ordonnansies uit te vaardig tov vlugtelinge en bannelinge, tot wetgewing daaroor aangeneem kan word.

25 Grundgesetz für die Bundesrepublik Deutschland. Hierna genoem die Grundgesetz. 
(1) The Federal Government, a Federal Minister or the Land governments may be authorised by a law to issue ordinances having the force of law (Rechtsverordnungen). The content, purpose and scope of the authorization so conferred must be set forth in such law. This legal basis must be stated in the ordinance. If a law provides that such authorization may be delegated, such delegation shall require another ordinance having the force of law. ${ }^{26}$

Uit hoofde hiervan is dit duidelik dat die legaliteitsbeginsel in die Duitse reg vereis dat magtigende wetgewing 'n voorvereiste is vir die uitoefening van administratiewe bevoegdhede. $^{27}$ De Ville meen dat dit immers 'n fundamentele vereiste is van die trias politica in 'n demokratiese regstaat dat die uitvoerende gesag slegs op gesag van die volksverteenwoordigers mag inbreuk maak op die regte en vryhede van die individu. ${ }^{28}$ Gevolglik mag die wetgewer steeds diskresionêre bevoegdhede aan die uitvoerende gesag verleen, maar alle wesenlike aangeleenthede moet deur die wetgewer self gereël word volgens die sogenaamde Wesentlichkeitstheorie. ${ }^{29}$ Hierdie beginsel is reeds in $1959^{30}$ so neergelê deur die Duitse Federale Konstitusionele Hof en weer eens bevestig in 1978: $:^{31}$

The rule of law requires that the administration can interfere with the rights of an individual only with the authority of law and that the authorization is clearly limited in its contents, subject-matter, purpose and extent so that the interference is measurable and to a certain extent is foreseeable and calculable by the citizen. ${ }^{32}$

\footnotetext{
26 Singh German Administrative Law 160.

27 De Ville 1993 SAPR 73.

28 De Ville 1993 SAPR 73.

29 De Ville 1993 SAPR 74 en Singh German Administrative Law 84.

309 BVerfGE 137, 147.

3149 BVerfGE 89, 157-159.

32 Singh German Administrative Law 84.
} 
Met die toepassing van hierdie beginsel het die hof wetgewing ongrondwetlik bevind wat die verkryging van 'n permit vir die plant van wingerdlote vereis het, maar wat nie die voorwaardes neergelê het waaronder die permit toegestaan kon word nie. ${ }^{33}$ Dit was ook die geval met 'n wet wat dateer het uit die dae van Nasionaal-Sosialistiese Duitsland wat die verlening van toestemming om openbare vergaderings te kon hou aan die subjektiewe diskresie van die polisie oorgelaat het. ${ }^{34}$ Vir so 'n wet om grondwetlik te kon wees, sou die wetgewer, indien hy die uitoefening van fundamentele regte onderhewig wou stel aan die voorafverkreë toestemming van die polisie, self die voorwaardes vir die toestemming of weiering tot die openbare vergadering moes neerlê. ${ }^{35}$

'n Soortgelyke posisie bestaan ten opsigte van verhoudinge waarin die individu nie enkel alleen teenoor die staat te staan kom met individuele regte nie, maar as lid van een of ander instelling of staatsdepartement waar hy in 'n posisie van ondergeskiktheid verkeer, byvoorbeeld as student, gevangene, staatsdiensamptenaar of lid van die weermag. In 1972 het 'n gevangene beswaar aangeteken teen die weerhouding van een van sy briewe aan 'n vriend waarin hy negatiewe opmerkings oor die gevangenisowerhede gemaak en kritiek teen die toestande in die gevangenis uitgespreek het. Hierdie brief is deur die gevangenisowerheid van die ontvanger daarvan weerhou op grond van 'n interne administratiewe voorskrif. Gevolglik het die Bundesverfassungsgericht beslis dat hierdie gesagsverhoudinge ook deur wetgewing gereël moes word en dat blote administratiewe voorskrifte onvoldoende was wanneer fundamentele regte aangetas word. ${ }^{36}$

Kort hierna is dieselfde beginsel uitgebrei na besluite met betrekking tot skole. Dié besluite moet egter verband hou met die verwesenliking van fundamentele regte. Ten opsigte van skole verwys dit onder andere na besluite wat verband hou met die bepaling van inhoud of objekte van onderwys, sillabusse, die organisatoriese struktuur van skole en die regstatus van leerlinge. ${ }^{37}$ Waar dit kom by die administrasie van

338 BVerfGE 71 in De Ville 1993 SAPR 75 en Singh German Administrative Law 84.

3420 BVerfGE 150 157-158 in De Ville 1993 SAPR 75 en Singh German Administrative Law 84.

35 De Ville 1993 SAPR 75 en Singh German Administrative Law 84.

3633 BVerfGE 1 in De Ville 1993 SAPR 76 en Singh German Administrative Law 70.

3734 BVerfGE 165 in De Ville 1993 SAPR 76 en Singh German Administrative Law 70. 
staatsdepartemente of dienste wat deur die staatsadministrasie gelewer word, is die algemene reël dat interne aangeleenthede wel deur selfgeskepte interne regulasies gereël kan word, sonder die vereiste van wetgewing, maar die struktuur van die administrasie moet in sy geheel steeds deur wetgewing gereël word. Wanneer hierdie organisatoriese regulasies egter die belange van buitestaanders raak, moet dit op wetgewing gebaseer wees. $^{38}$

Dit wil dus blyk dat die reël uit hoofde van artikel 80(1) van die Grundgesetz soos volg daar uitsien: hoe belangriker die aangeleentheid in die geheel en vir die lid van die betrokke instelling, of by die aantasting van die regte van buitestaanders, hoe noukeuriger moet die aangeleentheid in wetgewing gereël word. Verder beïnvloed die belangrikheid van die betrokke aangeleentheid ook die uitleg van die magtigende wetgewende bepaling soos dit in artikel 80(1) neergelê is. Hoe belangriker die aangeleentheid, hoe duideliker moet die magtigende bepaling geformuleer word vir die Rechtsverordnungen en die betrokke magtigende bepaling om die toets van grondwetlikheid te kan slaag. ${ }^{39}$ Die magtigende wet mag nie so vaag wees dat nie voorsien kan word in watter omstandighede en met watter doel die gesag uitgeoefen sal word of wat die inhoud van die verordening sal wees wat op gesag van daardie magtigende bepalings uitgevaardig sal word nie. ${ }^{40}$

'n Wet wat algemene gesag aan die federale Minister van Binnelandse Sake verleen het om die herorganisasie van die Länder deur verordeninge te reël, is ook ongrondwetlik verklaar weens die vaagheid daarvan. ${ }^{41}$ Dieselfde was die geval met 'n wet wat algemene gesag aan die federale regering verleen het om gedetailleerde bepalings uit te vaardig ten opsigte van die voorwaardes om as Duitse krygsgevangenes te kon kwalifiseer, sonder dat dit die doel en omvang van daardie gesag uitgespel het. ${ }^{42}$ Soortgelyk was die algemene verkoopsbelastingwet se bepalings wat die federale Minister van Finansies

40 BVerfGE 237 in Singh German Administrative Law 70.

58 BVerfGE 257278 in De Ville 1993 SAPR 76-77.

1 BVerfGE 14 60; 20, 57 69; 34, 5260 in De Ville 1993 SAPR 77-78.

411 BVerfGE 1460 in De Ville 1993 SAPR 78 en Singh German Administrative Law 21.

425 BVerfGE 7177 in Singh German Administrative Law 21. 
gemagtig het om ordonnansies uit te vaardig vir die gelykstelling van enkel- en meervlakkige ondernemings vir doeleindes van die betaling van algemene verkoopsbelasting. Hierdie wet se probleem was dat dit nie sodanige ondernemings gedefinieer of die metodes uiteengesit het wat die Minister kon aanwend vir die doeleindes van gelykstelling nie. ${ }^{43}$

Dit is egter nie nodig dat die inhoud, omvang en doel van die delegasie altyd uitdruklik in die magtigende wet vermeld hoef te word nie. Indien dit duidelik uit daardie wet afgelei kan word deur die toepassing van die beginsels en metodes van wetsuitleg, sowel as oorweging van ander verwante statutêre bepalings en die oorsprong en agtergrond van die betrokke wetgewing, dan blyk die vereiste bevredig te wees. ${ }^{44}$ Weens die regstaatbeginsel is hierdie vereiste natuurlik strenger waar daar op fundamentele regte inbreuk gemaak word. Magtiging moet so duidelik omskrewe wees dat daar uit die magtigende wet (en nie die uiteindelike verordening nie) blyk wat die posisie is. ${ }^{45}$

Hieroor het die Bundesverfassungsgericht beslis dat ten opsigte van die strafregwetgewing en die wetgewing wat persoonlike vryheid aantas, die uitvoerende gesag gemagtig kan word om strafregordonnansies uit te vaardig. Die magtiging ten opsigte van die inhoud, doel en omvang moet egter duidelik genoeg wees dat die voorwaardes vir kriminele optrede en die straf daaraan verbonde duidelik voorsienbaar moet wees vanuit die magtiging self en nie vanuit die ordonnansie van die uitvoerende gesag nie. Verder moet die magtigende wet duidelik die omvang en soort straf vermeld alhoewel die vasstelling van die feite of elemente wat die oortreding uitmaak, aan die gedelegeerde oorgelaat kan word. ${ }^{46}$ Die Bundesverfassungsgericht het hierdie beginsel ook uitgebrei na wetgewing wat deur die Länder uitgevaardig word. ${ }^{47}$

437 BVerfGE 282 in Singh German Administrative Law 21.

4455 BVerfGE 207 226-227 in De Ville 1993 SAPR 78 en Singh German Administrative Law 21.

457 BVerfGE 282302 in De Ville 1993 SAPR 78 en Singh German Administrative Law 22.

4614 BVerfGE 245 251; 14, 174185 in Singh German Administrative Law 22.

4754 BVerfGE 143 in Singh German Administrative Law 22. 


\subsection{Samevatting ten opsigte van die Duitse Regsposisie}

Duitsland se regsposisie ten opsigte van delegasie sien dus soos volg daar uit: enige wetgewende delegasie wat ondergeskikte wetgewing magtig, moet aan sekere vereistes voldoen. Hierdie vereistes is dat die doel, inhoud en omvang van die magtiging uit die magtigende wetgewing self moet blyk en nie uit die delegasie of die uitgevaardigde ordonnansie nie. Dié inhoud, omvang en doel mag natuurlik uit die ordonnansie blyk. Dit mag net nie vir die éérste keer in daardie wetgewende bepaling voorkom, sodat dit eintlik deur die gedelegeerde gesag daargestel is nie. ${ }^{48}$

\section{Die Suid-Afrikaanse regsposisie na 1994}

\subsection{Algemeen}

Dit is algemene kennis dat Suid-Afrika op 27 April 1994 'n volledige breuk met die verlede gemaak het, beide op politieke en staatsregtelike gebied. Met die inwerkingtrede van die Oorgangsgrondwet het ons die bedeling van 'n demokratiese regstaat betree waar die soewereiniteit van die Parlement met 'n onverskanste Grondwet, soos wat ons daaraan gewoond was uit die ou Westminster-bedeling, vervang is met die oppergesag van die reg waar die Grondwet voortaan die hoogste reg in die Republiek sal uitmaak. ${ }^{49}$

Hierdie beginsel is voortgesit in die finale Grondwet van $1996 .{ }^{50}$ Uit die aard van die saak sal hierdie onomkeerbare breuk met die verlede ernstige gevolge inhou, ook vir die gesag wat die Parlement as sentrale wetgewende gesag van die Republiek sal kan delegeer. $^{51}$ In hierdie geval is dit dan spesifiek met verwysing na die delegasie van

48 Singh German Administrative Law 22. Uit 4.2.3 en 4.2.4 hieronder wil dit voorkom of 'n soortgelyke benadering in die Suid-Afrikaanse reg gevolg word.

49 A 4 van die Oorgangsgrondwet Grondwet van die Republiek van Suid-Afrika 108 van 1996 en a 1(c) en 2 van die 1996-Grondwet. Sien ook die opmerkings hieroor in Executive Council, Western Cape Legislature $v$ President of the RSA 19954 SA 877 (KH) 899F-H.

50 Dit is verseker deur Grondwetlike Beginsel IV van die Oorgangsgrondwet wat bepaal het: "Die Grondwet moet die hoogste reg van die land wees."

51 A 43 en 44 van die 1996-Grondwet setel die nasionale wetgewende gesag in die Parlement. Vgl a 37 van die Oorgangsgrondwet. 
wetgewende kompetensies aan die uitvoerende gesag. Dit het ook nie baie lank geneem voordat hierdie aangeleentheid homself in ons howe voorgedoen het ten einde duidelikheid daaroor te kon verkry nie.

\subsection{Die houding van die Konstitusionele Hof}

Die kwessie aangaande die grondwetlikheid van wetgewende diskresies van die uitvoerende gesag ten opsigte van die maak van ondergeskikte wetgewing het in sy kort bestaan al twee keer voor die Konstitusionele Hof gedien, maar beide sake is beslis terwyl die Oorgangsgrondwet nog gegeld het. Hierdie Grondwet het 'n nuwe staatsregtelike bedeling ingelui wat parlementêre gesag om wetgewing te maak beperk het ten opsigte van inhoud en prosedure, in teenstelling met die pre-1994 soewereine parlement. ${ }^{52}$ In die eerste van hierdie sake, Ynuico Ltd v Minister of Trade and Industry ${ }^{53}$ het dit gehandel oor die grondwetlikheid van wetgewende diskresies wat aan die uitvoerende gesag gedelegeer is ingevolge wetgewing wat deur die Parlement gepromulgeer is voor die inwerkingtrede van die regstaatlike bedeling in 1994. Daarteenoor het Executive Council, Western Cape Legislature $v$ President of the Republic of South Africa ${ }^{54}$ weer gehandel oor die posisie van wetgewing wat deur die eerste demokraties verkose parlement aangeneem is sedert die inwerkingtrede van die Oorgangsgrondwet. Hierdie saak het spesifiek gehandel oor die wetgewende diskresies wat aan die President gedelegeer is. ${ }^{55}$

\subsubsection{Die Ynuico-beslissing}

In casu was die regsvraag of die delegasie van wetgewende gesag aan die uitvoerende gesag ingevolge wetgewing wat gepromulgeer is voor die inwerkingtrede van die

52 Executive Council, Western Cape Legislature v President of the RSA 19954 SA 877 (KH) 903F-G, 904B-F en 932C-D.

53 Ynuico Ltd $v$ Minister of Trade and Industry 19966 BCLR 798 (KH).

54 Executive Council, Western Cape Legislature v President of the RSA 19954 SA 877 (KH).

55 Dit is interessant dat regter Didcott in die Ynuico-beslissing die vraag oor wetgewing aangeneem na 1994 obiter genoem het, maar verkies het om dit onbeantwoord te laat in par 4 van daardie uitspraak. 
Oorgangsgrondwet, wat die regstaatlike bedeling ingelui het, ingevolge daardie Grondwet aangeval kon word. Die vraag was of so 'n delegasie ongrondwetlik was. Delegasie het in die betrokke geval geskied by wyse van artikel 2(1)(b) van die Wet op die Beheer van In-en Uitvoere 45 van 1963. Artikel 2(1)(b) lui soos volg:

Die Minister mag, wanneer hy dit ookal noodsaaklik en dienstig ag vir die openbare belang, by kennisgewing in die Staatskoerant voorskryf dat geen goedere van 'n gespesifiseerde klas of soort of geen ander goedere as goedere van 'n gespesifiseerde klas of soort ... ingevoer sal word in die Republiek nie, behalwe onder gesag van en in ooreenstemming met die voorwaardes gestel in 'n permit deur hom uitgereik of deur 'n persoon deur hom daartoe gemagtig ...

Uit hoofde van hierdie artikel het die Minister van Handel en Nywerheid gevolglik op 23 Desember 1988, Goewermentskennisgewing R2582 uitgevaardig ingevolge waarvan die invoer van onder andere tee, verbied is, indien dit sonder 'n permit sou geskied. As 'n voorsiener van tee is die applikant in die huidige aangeleentheid verbied om tee in te voer tensy hy vooraf 'n persentasie van die plaaslike produksie van tee sou aankoop - 'n maatreël ingestel om plaaslike produsente te beskerm. ${ }^{56}$

A quo is in die Transvaalse provinsiale afdeling ${ }^{57}$ aangevoer dat artikel 2(1)(b) onversoenbaar sou wees met artikels 24 en 26(1) van die Oorgangsgrondwet wat op daardie stadium nog in werking was. Daar is aangevoer dat dit nie aan die vereistes van administratiewe geregtigheid in artikel 24 voldoen het nie, weens die ongenoegsaam gedefineerde en omskrewe gesag van die Minister. Verder was die argument dat dit aan die Minister die reg verleen het om inbreuk te maak op die applikant se reg om vrylik aan die ekonomiese verkeer deel te neem volgens artikel 26. Nie een van hierdie argumente is egter in die Konstitusionele hof voortgesit nie (die uitspraak meld nie waarom nie) en

56 Par 2 van die uitspraak.

57 Ynuico Ltd $v$ Minister of Trade and Industry 1995 (11) BCLR 1453 (T). 
gevolglik is daar geen beslissings op grond daarvan gemaak nie. ${ }^{58}$ Daar is eerder gefokus op artikel 37 van die Oorgangsgrondwet wat die wetgewende gesag van die Republiek in die Parlement gesetel het om grondwetlik versoenbare wette te kon maak. Die applikant het aangevoer dat slegs die Parlement ingevolge hierdie artikel met volkome wetgewende gesag beklee is. Daardie Grondwet het nêrens toegelaat dat enige deel van die Parlement se soewereine wetgewende gesag aan 'n Minister oorgedra kon word nie en gevolglik was 'n delegasie soos dit in artikel 2(1)(b) voorgekom het ongrondwetlik, omdat dit in stryd met artikel 37 en dus onversoenbaar was met die Grondwet as hoogste reg volgens artikel 4 daarvan. ${ }^{59}$ Dit sou die geval wees omdat dit aan die Minister 'n carte blanche verleen het ten opsigte van ondergeskikte wetgewing binne die afgebakende jurisdiksiegebied van artikel 2(1)(b), sonder enige neergelegde riglyne of kriteria oor die uitoefening van sy gesag, behalwe soos hy dit "ookal noodsaaklik en dienstig [sou ag] vir die openbare belang." Dit was 'n beperking wat volgens die applikant so algemeen, onbepaald en subjektief was dat dit in effek op niks in substansie of waarde neergekom het nie. ${ }^{60}$

Hierdie argumente word egter deur die hof van die tafel gevee omdat dit irrelevant is in die betrokke saak. ${ }^{61}$ Die ratio hieragter is die volgende: die bewoording en konteks van die onderhawige artikel dui daarop dat dit slegs handel oor die setel en bron van wetgewende gesag na inwerkingtrede van die Oorgangsgrondwet ${ }^{62}$ en dat die posisie voor 1994 onaangeraak gelaat word. Daar word byvoorbeeld verwys na die toekomstige tydvorm waarin die teks geskryf is, die feit dat daar in hoofstuk vier van daardie Grondwet na die Parlement verwys word as die Nasionale Vergadering en die Senaat, en die verwysing na, "behoudens hierdie Grondwet." Volgens die hof sou dit tog duidelik

58 Par 3 van die uitspraak.

59 Par 9 en 10 van die uitspraak.

60 Par 4 en 9 van die uitspraak.

61 Dit was in lyn met ' $n$ vroeëre beslissing van regter Marais in die Witwatersrandse Plaaslike Afdeling op 28 September 1995 - 'n ongerapporteerde beslissing, $S$ v Coetzee 70/92.

62 A 229 van die Oorgangrondwet het bepaal dat alle wette wat onmiddellik voor die inwerkingtrede van daardie Grondwet van krag was binne enige gebied wat deel van die nasionale grondgebied uitmaak, van krag sou bly behoudens daardie Grondwet en behoudens enige herroeping of wysiging van sodanige wette deur enige bevoegde gesag. 
nie kon verwys na 'n vorige parlementêre bedeling toe die Oorgangsgrondwet nog nie ingetree het nie. ${ }^{63}$

Artikel 2(1)(b) is juis verorden voor 1994 toe die Parlement soewerein was en wetgewing na goeddunke kon verorden en aan enige Minister (of enigiemand anders) onbeperkte wetgewende gesag kon delegeer. Daardie soewereine Parlement het ook nie gehuiwer om dit te doen nie. ${ }^{64}$ Hierdie artikel word uiteindelik beslis om ingevolge artikel 229 te geld $^{65}$ en sodoende van toepassing te wees in ons reg ingevolge die argumente wat voor die hof aangevoer is. Daar is niks in gemelde artikel wat blyk dat dit 'n hoër waarde het as artikel 229 nie. Laasgenoemde artikel is dus nie daaraan onderhewig gestel nie. Dus word die gelding van artikel 229 in casu nie aangetas ten opsigte van die artikel 2(1)(b) se gelding in ons reg nie en bly laasgenoemde voortbestaan ingevolge daarvan. ${ }^{66}$

Die laaste argument wat deur die hof verwerp is ten opsigte van die onderhawige artikel 37 was dat die Parlement sedert die inwerkingtrede van die Oorgangsgrondwet stilswyend tot artikel 2(1)(b) toegestem, en die bepalings daarvan aangeneem het deur dit nie te herroep of te wysig nie. Hierdie argument sou impliseer dat die Parlement ook wette sou kon maak, deur nie wette te makk nie. Dit stel die parlementêre proses van debattering oor wetsvoorstelle wat uitloop op behoorlike prosesse van oorweging daarvan, gelyk met 'n totale gebrek aan beide. Volgens hierdie lyn van argumentering word daar dan aan die Parlement 'n positiewe besluit toegereken, sonder om in ag te neem wat in werklikheid die besluit van die Parlement sou gewees het as dit wel behoorlik aandag sou geskenk het aan die wetgewing. ${ }^{67}$ So 'n gevolgtrekking is, aldus die hof, ondenkbaar.

Dit bly egter onduidelik wat die beslissing sou gewees het indien die applikant sy oorspronklike argumente, soos dit a quo geformuleer is aangaande artikel 2(1)(b), voor

63 Par 6 en 10 van die uitspraak.

64 Par 7 van die uitspraak en sien ook 2.2 en 4.1 hierbo.

65 Hierdie artikel sit die toepassing van wetgewing wat van krag was voor die inwerkingtrede van die Oorgangsgrondwet voort.

66 Par 10 van die uitspraak. 
die Konstitusionele Hof voortgesit het. Die Konstitusionele Hof het egter nooit die geleentheid gehad om daaroor te beslis nie - slegs bogenoemde argumente oor die toepassing van artikel 37 was in daardie hof ter sprake. Die rede hiervoor is dat geen wetgewende bepaling, ook nie een wat ingevolge artikel 229 voortgesit is, die grondwetlike toets sou kon slaag, indien dit in stryd met die fundamentele regte sou wees soos dit gewaarborg is in die Grondwet nie. ${ }^{68}$

\subsubsection{Die geldigheid van die Ynuico-beslissing ingevolge die 1996-Grondwet}

'n Vraag wat beantwoord moet word is of die gevolgtrekkings van die hof ook geldig is ingevolge die huidige Grondwet. Swart ${ }^{69}$ en Chaskalson ${ }^{70}$ meen dat die bepalings van die finale Grondwet in belangrike opsigte van die Oorgangsgrondwet verskil. Daarom is hulle van mening dat hierdie beslissing tans nie veel waarde het nie.

In die eerste plek bepaal die Grondwet in artikel 2 dat enige reg of optrede in stryd daarmee ongeldig is. Verder word in item 2(1) van Bylae 6, saamgelees met artikels 242 en 243, bepaal dat alle reg wat van krag is wanneer die Grondwet in werking tree, van krag sal bly, onderhewig aan die versoenbaarheid daarvan met die Grondwet. ${ }^{71}$ Dit verskil aansienlik van artikel 229 van die Oorgangsgrondwet wat geen soortgelyke bepaling bevat het nie, maar bloot die gelding van wetgewing voortgesit het in die betrokke gebied waar dit van toepassing was, totdat dit herroep of gewysig is. Hierdie veranderinge se gevolg is dat die instandhouding van wette wat voor 1996 in werking getree het, nie verleng sal word ingevolge die finale Grondwet indien daardie wette ongrondwetlik is nie. Indien hierdie gevolgtrekking korrek sou wees dan sal dit beteken dat wette wat in stand gehou is ingevolge die Oorgangsgrondwet slegs in stand gehou sal word tot die mate dat dit in lyn is met die finale Grondwet. Dit kan beteken dat ook

67 Par 11 van die uitspraak.

68 Par 8 van die uitspraak.

69 Swart 1996 SAPR 455-456.

70 Chaskalson Constitutional Law 3-5.

71 'n Bepaling van die Wet op Arbeidsverhoudinge 66 van 1995 bly egter geldig ten spyte van die bepalings van die Grondwet, totdat daardie bepaling gewysig of herroep word. 
gedelegeerde gesag, soos in wetgewing wat voor 1994 gepromulgeer is, vervat, nou ongrondwetlik kan wees, in stryd met die beslissing in Ynuico. ${ }^{72}$ Sodoende kan die beslissing in Ynuico nie meer net so toegepas word nie, weens hierdie belangrike verandering wat in die finale Grondwet aangebring is.

\subsubsection{Die Executive Council, Western Cape Legislature-beslissing}

Een van die kwessies wat in hierdie saak voor die hof gedien het, was die vraag oor die grondwetlikheid van artikel 16A van die Oorgangswet op Plaaslike Regering 209 van 1993. Hierdie artikel het aan die President die gesag verleen om die betrokke wet en sy bylaes by wyse van proklamasie in die staatskoerant te wysig. Die wysiging moes steeds geskied met die goedkeuring van die portefeuljekomitees op staatkundige ontwikkeling van die Nasionale Vergadering en die voormalige Senaat. Verder moes sulke wysigings in die Parlement ter tafel gelê word en dit sou wegval indien dit deur die Parlement afgekeur is. $^{73}$ Die President het sodanige wysigings aangebring by wyse van Proklamasies R58 van 7 Junie 1995 en R59 van 8 Junie 1995. Dit het ingehou dat artikel 3(5) van die wet sodanig gewysig is dat die gesag om komiteelede van die Uitvoerende Rade van die provinsies aan te wys, vanaf die provinsiale regering na die nasionale regering oorgedra is. Ook is artikel 10 gewysig sodat die administrateur se afbakeningsgesag onderhewig gestel is aan 'n nuwe artikel 10(4) van die wet wat afbakenings voor Proklamasie R58 in effek nietig verklaar het. ${ }^{74}$ Uiteindelik sou die uitkoms van hierdie kwessies bepalend wees vir 'n politieke afbakeningsdispuut oor gebiede in die Kaapse skiereiland met die oog op die verkiesing van plaaslike owerhede in November 1995, want die samestelling van die komitees sou 'n invloed op die afbakening gehad het.

Daar was niks in die Oorgangsgrondwet wat die Parlement verbied het om ondergeskikte regulerende gesag aan ander liggame te delegeer nie en dit is noodsaaklik vir die daarstel

72 Swart 1996 SAPR 456.

73 Par 10 van die uitspraak.

74 Par 13 van die uitspraak. 
van effektiewe wetgewing. Verder blyk dit ook implisiet uit die bewoording van artikel 37 van die Oorgangsgrondwet wat die wetgewende gesag van die Republiek in die Parlement gesetel het om wette ooreenkomstig die bepalings van die Oorgangsgrondwet te kon maak. ${ }^{75}$ Maar, daar is 'n verskil tussen die delegasie van die gesag om ondergeskikte wetgewing te maak en die delegasie aan die uitvoerende gesag van die gesag om wette van die Parlement te wysig of te herroep. ${ }^{76}$ So 'n delegasie sou ondermynend wees van die "manner and form"-vereistes soos dit in artikels 59, 60 en 61 van die Oorgangsgrondwet voorgekom het. Hierdie grondwetlike artikels was volgens die hof nie bloot aanwysende bepalings nie, maar het beskryf hoe wetgewing gemaak en gewysig moes word. Hierdie grondwetlike artikels was deel van 'n skema wat die deelname van albei huise van die Parlement verseker het in die uitoefening van die wetgewende gesag wat in die Parlement gesetel was en het ook meganismes daargestel wat van toepassing sou wees wanneer dooiepunte sou voorkom. ${ }^{77}$

Regter Sachs ${ }^{78}$ is van mening dat dit oor meer handel as bloot die vraag of dit 'n parlementswet is wat absolute gesag om wetgewing te maak aan die uitvoerende gesag oordra. So 'n delegasie sal ontoelaatbaar wees. 'n Wet wat die gesag uitbrei om ondergeskikte wetgewing te kan maak, sal daarenteen wel grondwetlik die toets kan slaag. 'n Onderskeid van hierdie aard sou eerder 'n kwessie van graad as van substansie wees. Daar moet eerder gelet word op die vraag of die delegerende wet verantwoordelikhede probeer afskud, wat in die omstandighede van die besondere saak en met inagneming van die spesifieke rol, verantwoordelikheid en funksie wat die Parlement het, nie aan enige ander liggaam toevertrou behoort te word nie. Dit sal onder andere 'n oorweging van die volgende faktore inhou:

(a) die omvang waartoe die diskresie van die gedelegeerde gestruktureer word deur die magtigende wet;

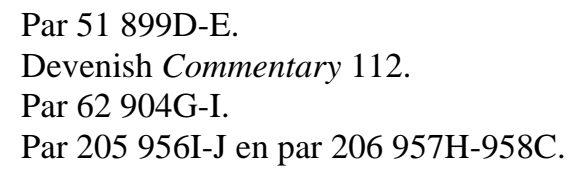


(b) die openbare en grondwetlike belangrikheid van die maatreël - hoe meer dit handel oor kwessies van openbare belangrikheid, hoe groter sal die behoefte wees vir goedkeuring deur die Parlement;

(c) hoe kort die tydperk is wat betrokke is;

(d) die omvang waartoe die Parlement aanhou om beheer uit te oefen as openbare forum waar kwessies behoorlik gedebatteer en besluite demokraties geneem kan word;

(e) die omvang waartoe die onderwerpinhoud die gebruik van vorme van vinnige inmenging benodig en wat deur die stadige parlementêre prosesse geïnhibeer sou word; en

(f) enige aanduidings dat so 'n delegasie uitdruklik of by noodwendige implikasie in die Grondwet self voorsien is. ${ }^{79}$

Artikel 16A het onbeperkte gesag aan die President verleen om die Oorgangswet op Plaaslike Regering ${ }^{80}$ te wysig $^{81}$ en om selfs die basiese beleidsbesluite deur die Parlement neergelê terwyl dit in sitting was, te wysig. ${ }^{82}$ In die wet is daar geen riglyne, aanwysings of besluitnemingskriteria oor die uitoefening van die President se wetgewende gesag uitgestippel nie ${ }^{83}$ en het dus daarop neergekom dat die beheer oor wetgewing vanaf die Parlement na die uitvoerende gesag oorgegaan het. ${ }^{84}$ Sodanige gesag kan nie geregverdig word op grond van noodsaaklikheid of by noodsaaklike implikasie vanuit die Oorgangsgrondwet nie. Die "manner and form"-vereistes van artikels 59, 60 en 61 was deel van 'n verskanste Grondwet wat oppergesag geniet het in die reg. Om daarvan te kon afstap sou slegs moontlik wees as die Oorgangsgrondwet dit uitdruklik of by noodwendige implikasie gemagtig het. In casu was nie een van hierdie

79 Adjunk-President Mahomed het na soortgelyke faktore verwys in par 136 930E-G.

80 Oorgangswet op Plaaslike Regering 209 van 1993.

81 Par 65 906H-I.

82 Par 137 931G-I.

83 Par 137 931J, par 141 933F-G en par 209 958H. Regter Sachs gaan in par 209 958I-J selfs so ver as om te beslis dat indien behoorlike riglyne wel uitgespel is, a $16 \mathrm{~A}$ sonder twyfel die toets van grondwetlikheid sou kon slaag. In Malherbe 1996 TSAR 178-179 word daar egter skerp van hierdie opinie verskil. Die rede is daarin geleë dat indien wetswysigings die bevoegdhede en werksaamhede van die provinsies sou raak, dit steeds ongeldig sou gewees het, omdat dit by proklamasie en nie ooreenkomstig die a 61-prosedure aangeneem is nie.

Par 63 905E-F. 
vereistes teenwoordig nie en dus was artikel 16A ongrondwetlik. ${ }^{85}$ Die Parlement sou tog nie die uitvoerende gesag kon magtig om wysigings te maak van 'n aard wat die Parlement self nie sou kon doen sonder om te voldoen aan hierdie vereistes nie. ${ }^{86}$

Twee van die regters, President Chaskalson ${ }^{87}$ en Adjunk-President Mahomed $^{88}$ (Hoofregter sedert 1996), was van mening dat daar dalk uitsonderlike omstandighede sou kon bestaan, byvoorbeeld oorlog of noodtoestand, of selfs omstandighede wat nie so erg sou wees nie, soos 'n nasionale ramp weens 'n vloed, waar dit by noodwendige implikasie sou kon blyk dat wette gemaak sou kon word sonder om aan hierdie "manner and form"-vereistes te voldoen. Regters O' Regan, Ackermann en Kriegler het egter verkies om hierdie kwessie oop te laat, omdat dit onsekerheid kon skep oor die aard van die Grondwet. Die moontlikheid sou ook kon ontstaan dat ander staatsregtelike oplossings hulself sou kon voordoen om in sulke omstandighede mee te handel, anders as om van die "manner and form"-bepalings af te sien. ${ }^{89}$

Wat wel vasstaan, is dat die artikel 16A-bepalings 'n ontoelaatbare delegasie ingehou het. ${ }^{90}$ Voorts is die gevolg van hierdie beslissing dat daar wel regsbeperkinge in die Suid-Afrikaanse reg bestaan ten opsigte van die wetgewende gesag wat deur die Parlement gedelegeer kan word. Dit kan nie onbeperk geskied nie. Hierdie gevolgtrekking van die hof is die logiese uiteinde van die leerstuk van die skeiding van magte in die Suid-Afrikaanse reg. ${ }^{91}$

\subsubsection{Die posisie ingevolge die finale Grondwet}

85 Par 62 905C-E, par 101 919A-B, par 143 934E-F, par 151 936F-G, par 160 940I-J, par 192 953C-D en $\mathrm{H}-\mathrm{I}$ en par 211 en 212 959F-G.

86 Par 137 932B-C, par 151 936F-G, par 192 953D-E en par 209 958I-J.

87 Par 62 904I-905B. Hierdie siening is gebaseer op bepalings van a 4(1) van die Oorgangsgrondwet.

88 Par 140 933C-E.

89 Par 150 936B-E en par 160 904I-J.

90 Chaskalson Constitutional Law 3-4.

91 Devenish Commentary 111. 
Soos die Oorgangsgrondwet, is die finale Grondwet tans die hoogste reg in die Republiek en ingevolge artikel 2 daarvan, is enige optrede of wet wat met die Grondwet in stryd is ongeldig en moet enige verpligtinge wat deur die Grondwet opgelê word, uitgevoer word. Dit word verder as grondwetlike waarde bevestig dat die Grondwet die hoogste reg in die land is. ${ }^{92}$ Die enigste gevolgtrekking wat hieruit gemaak kan word is dat die Parlement ook aan die Grondwet gebonde is en nie die bepalings daarvan kan omseil soos voor 27 April 1994 nie.

Die ooreenstemmende artikel wat die nasionale wetgewende gesag van die Republiek in die Parlement vestig, is artikel 43(a). ${ }^{93}$ 'n Totaal nuwe artikel wat geen voorganger in die Oorgangsgrondwet het nie, is artikel 44(1)(a)(iii) wat aan die Parlement die gesag verleen om enige van sy wetgewende kompetensies, behalwe die gesag om die Grondwet te kan wysig, aan enige wetgewende liggaam in 'n ander regeringsfeer te kan opdra. Prima facie wil dit voorkom asof hierdie artikel die beslissing in die Western Cape Legislaturesaak omverwerp, maar so 'n argument word onmiddellik in twyfel getrek wanneer die bepalings van artikel 40 deeglik oorweeg word.

Artikel 40 bepaal dat die regering van die Republiek in drie regeringsfere verdeel word. Die wetgewende gesag van die nasionale sfeer word gesetel in die Parlement ${ }^{94}$ wat bestaan uit die Nasionale Vergadering en die Nasionale Raad van Provinsies. ${ }^{95}$ Wetgewende gesag van die provinsiale regeringsfeer setel weer in die onderskeie provinsiale wetgewers van die nege provinsies en die plaaslike regeringsfeer se wetgewende gesag word deur die munisipale rade beheer. ${ }^{96}$ Die begrip "sfeer" verwys dus nie na 'n deel of liggaam van een of ander afdeling van die uitvoerende gesag nie, maar bloot na die nasionale, provinsiale of plaaslike owerheid wat met wetgewende gesag beklee word in die Grondwet, as onderskeibare regeringsfere. Dus het artikel 44(1)(a)(iii) geen invloed op die gesag wat die Parlement sou kon delegeer aan die

\footnotetext{
92 A 1(c).

93 A 37 in die Oorgangsgrondwet.

94 A 43(1).

95 A 42(1).

96 A 43(b)-(c).
} 
uitvoerende gesag, anders as wat die posisie ingevolge die Oorgangsgrondwet daar uitgesien het nie. Dit word bevestig deur artikel 44(4) wat die Parlement in die uitoefening van die wetgewende gesag slegs deur die Grondwet laat bind, sodat dit in lyn daarmee en binne die beperkinge van die Grondwet moet optree. Swart ${ }^{97}$ meen dit is opvallend dat die begrip uitvoerende gesag in artikel 44(1)(a)(iii) weggelaat is ten opsigte van die vraag aan wie die Parlement sy wetgewende gesag sal kan delegeer. Hy skryf dat die formulering van hierdie subartikel duidelik gemik is op die instandhouding van die skeiding van magte en dus sal die delegasie van die wetgewende gesag aan die uitvoerende gesag, buite die Parlement se vermoë val. Devenish skryf verder dat daar onderskei moet word tussen "legislative powers" soos dit in artikel 44(1)(a)(iii) voorkom en "plenary legislative powers". Hy meen dat die Grondwet net toelaat dat delegasie van ondergeskikte wetgewende gesag kan plaasvind. Die feit dat die Grondwet slegs daarna verwys dat die Nasionale Vergadering "legislative powers" kan delegeer en nie "plenary legislative powers" nie, blyk om die Parlement se vermoë om te delegeer, te beperk. ${ }^{98}$

Die Grondwet voorsien slegs die delegasie van ondergeskikte wetgewende gesag. Dit blyk implisiet uit die argument hierbo, sowel as die bewoording van artikel 44 en die implisiete afleiding uit subartikel 101(3), wat die enigste verwysing in die Grondwet na ondergeskikte wetgewing is. Hierdie subartikel is die enigste direkte verwysing in die Grondwet na ondergeskikte wetgewing en bepaal bloot ten opsigte van uitvoerende besluite dat proklamasies, regulasies en ander instrumente van ondergeskikte wetgewing vir die publiek toeganklik moet wees. Uit hoofde hiervan kan afgelei word dat daar dus geen twyfel bestaan dat die uitvoerende gesag wel die gesag het om ondergeskikte wetgewing te kan maak nie. Normaalweg sal dit egter in magtigende wetgewing wat deur die Parlement aangeneem word aan die uitvoerende gesag gedelegeer moet word. Die Parlement kan egter steeds nie essensiële of primêre wetgewende gesag aan die uitvoerende gesag oordra nie. Die Grondwet verleen aan die Nasionale Vergadering die gesag om die Grondwet self te kan wysig ${ }^{99}$ en wetgewing aan te neem ten opsigte van

97 Swart 1996 SAPR 461.

98 Devenish Commentary 332.

99 A 44(1)(a)(i) saamgelees met a 74 wat oor die prosedures handel by die wysiging van die Grondwet. 
enige aangeleentheid. Dit sluit ook aangeleenthede in wat binne 'n funksionele terrein of gebied val soos dit gelys is in Bylae 4 van die Grondwet. Bylae 4 handel oor sake waaroor die nasionale en provinsiale regeringsfere konkurrente bevoegdhede het. Die Nasionale Vergadering kan egter nie wetgewing aanneem oor aangeleenthede wat in Bylae 5 van die Grondwet gelys word nie, omdat Bylae 5 spesifiek handel oor aangeleenthede waaroor die provinsies eksklusiewe wetgewende bevoegdhede het. ${ }^{100}$ Hierdie beperking word egter deur subartikel 44(2) getemper deurdat die Parlement wetgewing mag aanneem in lyn met artikel 76(1), ${ }^{101}$ ook ten aansien van aangeleenthede wat binne die funksionele areas van Bylae 5 val. Dit sou slegs kon geskied wanneer dit noodsaaklik is vir doeleindes van nasionale veiligheid, om ekonomiese eenheid of essensiële nasionale standaarde in stand te hou, om minimum standaarde daar te stel wat nodig sou wees vir die lewer van dienste en laastens om onredelike optrede van 'n provinsie te voorkom wat nadelig sou wees vir die belange van 'n ander provinsie of die land as geheel. ${ }^{102}$

'n Verdere vraag kan ook ontstaan uit hoofde van hierdie gesag van die Parlement en die provinsiale wetgewers oor hul konkurrente en eksklusiewe bevoegdhede. Subartikel 44(3) se bewoording is die oorsprong van hierdie vraag juis omdat dit lui dat wetgewing ten opsigte van 'n aangeleentheid wat redelik noodsaaklik of insidenteel is vir die effektiewe uitoefening van gesag ten opsigte van 'n aangeleentheid in Bylae 4, vir alle praktiese doeleindes wetgewing is ten opsigte van 'n aangeleentheid wat in Bylae 4 gelys word. In eenvoudige taal beteken dit dat waar die nasionale en provinsiale regerings konkurrente wetgewende bevoegdhede het oor 'n saak, byvoorbeeld landbou of gesondheidsdienste, daardie bevoegdheid ook enige ander saak omvat wat noodsaaklik of bykomstig is vir die effektiewe uitoefening van 'n bevoegdheid in Bylae 4 gelys.

100 A 44(1)(a)(ii).

101 A 76(1) handel oor die prosedure by die verwysing van gewone wetsontwerpe wat die provinsies raak, na die Nasionale Raad van Provinsies (nie geldwetsontwerpe nie). Dit beskryf ook die oplos van dooiepunte indien so 'n wetsontwerp deur die Nasionale Raad van Provinsies afgekeur sou word.

102 A 44(2)(a)-(e). 
Kan daar nou geargumenteer word dat die delegasie van wetgewende gesag aan die uitvoerende gesag slegs plaasvind om die effektiewe uitoefening van gesag oor enige saak wat noodsaaklik of bykomstig is tot aangeleenthede wat in Bylae 4 gelys word, te verseker? Ook hieroor meen Swart dat dit nie die geval is nie, omdat die formulering van die betrokke bepaling en van die gelyste aangeleenthede in Bylae 4 van die Grondwet hierdie moontlikheid uitsluit. ${ }^{103}$ Hy meen dat die bewoording bloot daarop dui dat die bevoegdhede van die nasionale en provinsiale owerhede uitgebrei word om ook sake in te sluit wat wyer as bloot die lys in Bylae 4 is, maar die doel van hierdie subartikel was definitief nie om te voorsien dat wetgewende gesag aan die uitvoerende gesag gedelegeer kon word nie. Die implisiete afleiding uit artikel 101(3) bly natuurlik steeds staan dat ondergeskikte wetgewende gesag wel gedelegeer sal kan word. Wat belangrik is om by te sê is die feit dat selfs al sou iemand probeer om artikel 44(2) vir dié doel te misbruik om wetgewende gesag aan die uitvoerende gesag te delegeer, dit steeds nie kan plaasvind ten opsigte van sake wat binne die eksklusiewe bevoegdheid van die nasionale regeringsfeer val, byvoorbeeld oor 'n aangeleentheid soos verdediging nie.

Alhoewel artikel 44(1)(a)(iii) bepaal dat die Nasionale Vergadering enige van sy bevoegdhede, buiten die bevoegdheid om die Grondwet te wysig, aan enige ander wetgewende liggaam in 'n ander regeringsfeer kan opdra, kan dit slegs geskied ten opsigte van aangeleenthede wat binne die omvang van Bylaes 4 en 5 val. Dit sal nie kan geskied ten opsigte van byvoorbeeld 'n aangeleentheid soos verdediging of buitelandse sake nie. Hierdie is aangeleenthede waaroor die nasionale regeringsfeer eksklusiewe bevoegdheid het, aangesien dit uitgesluit is van Bylaes 4 en 5 . Die feit dat artikel 44(1)(a)(iii) dit stel dat enige wetgewende bevoegdheid gedelegeer kan word aan 'n ander wetgewende liggaam in 'n ander regeringsfeer, bevestig hierdie standpunt. Bevestiging is daarin geleë dat die bevoegdheid om die Grondwet te wysig uitgesluit word van bevoegdhede wat gedelegeer kan word aan ander wetgewende liggame in ander regeringsfere. Hiermee saam verwys die begrip wetgewende liggame in ander regeringsfere na die wetgewers in die provinsiale of die plaaslike regeringsfere en nie na enige lede van die uitvoerende gesag in enige regeringsfeer nie. Hierdie subartikel kan

103 Swart 1996 SAPR 462. 
dus nie misbruik word om ongeoorloofde delegasies aan die uitvoerende gesag teweeg te bring in enige regeringsfeer nie.

Nog 'n argument doen homself voor teen die delegasie van wetgewende gesag aan die uitvoerende gesag uit hoofde van wetgewing wat noodsaaklik is vir die effektiewe uitoefening van wetgewende gesag oor 'n besondere saak. Indien die wetgewende gesag om 'n heffing of 'n belasting op te lê aan die uitvoerende gesag gedelegeer sou word, sal dit kan beteken dat die uitvoerende gesag die gesag verleen word om die prosedures wat in die Grondwet neergelê is by die aanneem van geldwetsontwerpe, ${ }^{104}$ te omseil. So 'n delegasie sal direk in stryd wees met die beslissing in Western Cape Legislature dat die Parlement tog nie gesag wat hyself nie kan omseil, aan 'n ander liggaam kan delegeer om dit sodoende te omseil nie. Die "manner and form"-vereistes wat in die Grondwet neergelê is, is daar om nagekom te word en kan nie bloot geïgnoreer word nie. ${ }^{105}$ Dieselfde sal natuurlik die geval wees by gewone wetsontwerpe wat ook aan "manner and form"-vereistes moet voldoen en tot dieselfde omvang deur die nasionale wetgewende gesag nagekom moet word. ${ }^{106}$

Swart ${ }^{107}$ beantwoord hierdie vraag verder met spesifieke klem op die bepalings van die Grondwet wat dit as die hoogste reg in die Republiek bevestig. Dit gaan hier oor die moontlikheid wat President Chaskalson ${ }^{108}$ en Adjunk-President Mahomed ${ }^{109}$ in die Western Cape Legislature-saak oopgelaat het dat daar uitsonderlike omstandighede sou kon bestaan wanneer die "manner and form"-vereistes agterweë gelaat sou kon word. Hulle noem spesifiek gevalle soos oorlog of noodtoestand en selfs mindere

104 A 77 bespreek die "manner and form"-vereistes vir geldwetsontwerpe, saamgelees met a 73(2) en (3).

105 Hierdie nie-nakoming van die "manner and form"-vereistes was een van die hoofredes waarom a 16A van die Oorgangswet op Plaaslike Regering 209 van 1993 ongrondwetlik verklaar is in Executive Council, Western Cape Legislature v President of RSA 19954 SA 877 (KH) by par 62 905C-E, par 101 919A-B, par 143 934E-F, par 151 936F-G, par 160 940I-J, par 192 953C-D en H-I en par 211 en 212 959F-G.

106 Die "manner and form"-vereistes van gewone wetsontwerpe word in a 75 van die Grondwet neergelê ten opsigte van wetsontwerpe wat nie provinsiale aangeleenthede raak nie en in a 76 vir wetsontwerpe wat wel doen, saamgelees met a 73 .

107 Swart 1996 SAPR 463.

108 Par 62 904I-905B. Hierdie siening is gebaseer op bepalings van a 4(1) van die Oorgangsgrondwet.

109 Par 140 933C-E. 
omstandighede soos 'n vloed wat as 'n nasionale ramp beskou sou word, wat ook sou kon vereis dat die "manner and form"-vereistes nie nagekom hoef te word nie. Swart meen dat opmerkings soos dié wat deur die agbare regters gemaak is nie meer geldig is ingevolge die finale Grondwet nie. Die verskil is daarin geleë dat die formulering van die betrokke bepalings in die finale Grondwet, naamlik artikel 2 wat die Grondwet as hoogste reg waarborg, ${ }^{110}$ drasties met die Oorgangsgrondwet se reëling in artikel 4(1) verskil wanneer dit vergelyk word. Die vorige artikel 4(1) het bepaal dat enige wet of handeling wat met die bepalings van die Grondwet onbestaanbaar is, nietig is in die mate waarin dit aldus onbestaanbaar is. Anders as artikel 4(1) van die Oorgangsgrondwet, bepaal artikel 2 van die finale Grondwet bloot dat enige wet of handeling wat met die Grondwet onbestaanbaar is, ongeldig is. Geen uitsonderings kom voor nie en daardie wet of handeling word ook nie in stand gehou tot die mate wat dit wel bestaanbaar sou wees nie.

Daar word deur die finale Grondwet geen ruimte daarvoor gelaat dat die "manner and form"-vereistes agterweë gelaat kan word, selfs in uitsonderlike omstandighede soos deur die twee regters voorsien ingevolge die Oorgangsgrondwet nie. Die Parlement moet dus te alle tye ingevolge die Grondwet se bepalings optree en die "manner and form"bepalings nakom soos dit neergelê is vir geld- en gewone wetsontwerpe, ongeag of dit oor provinsiale aangeleenthede handel of nie. Die "manner and form"-bepalings is dwingend en moet nagekom word. Wanneer uitsonderlike omstandighede hulself sou voordoen, sal die Parlement maar net grondwetlike maniere moet vind om met die probleem voorhande te handel, maar om wetgewende gesag aan die uitvoerende gesag te delegeer sal uit die aard van die saak totaal buite die kwessie wees.

Bogenoemde gevolgtrekking word ook ondersteun deur die beleidsoorwegings waarop die bepalings in die Grondwet gefundeer is. Die rol van die "manner en form"-bepalings en die beleidskwessies daaroor kan slegs geëvalueer word binne die grondwetlike konteks en teen die agtergrond van die tema van grondwetlike waardes waarop die land gefundeer is, naamlik verantwoordingspligtigheid, 'n responsiewe ingesteldheid en

110 Saamgelees met a 1(c). 
openheid, soos dit in artikel 1(d) gestel is. Die feit dat die "manner and form"-vereistes in die finale Grondwet voorkom en daar is om nagekom te word deur die Parlement, is wyses om te verseker dat hierdie waardes soos in artikel 1(d) vervat, wel neerslag vind in ons regstaatlike bedeling.

Ons Nasionale Vergadering word verkies sodat die lede daarvan as verteenwoordigers kan dien ten einde verteenwoordigende regering te verseker ingevolge die Grondwet. Dit geskied onder andere deurdat die Nasionale Vergadering 'n openbare forum is vir die oorweging en debattering van belangrike kwessies van openbare belang en die aanneem van wetgewing. ${ }^{111}$ 'n Verpligting rus op die Parlement om openbare betrokkenheid te fasiliteer in die wetgewende en ander prosesse van die Nasionale Vergadering en die Nasionale Raad van Provinsies en hul komitees. ${ }^{112}$ Verder moet dit op 'n oop wyse geskied, moet die sittings sowel as dié van die betrokke komitees in die openbaar geskied $^{113}$ en die publiek mag slegs uitgesluit word indien dit onder die omstandighede redelik en regverdigbaar sou wees in 'n oop en demokratiese samelewing. ${ }^{114}$ Verder mag die Parlement interne reëls maak, maar slegs met behoorlike inagneming van verteenwoordigende en deelnemende demokrasie, verantwoordbaarheid, deursigtigheid en openbare betrokkenheid. ${ }^{115}$ Voorsiening moet ook daarin gemaak word vir die deelname in die verrigtinge van die Parlement se twee huise en hul komitees, van minderheidspartye, wat verteenwoordig is in die betrokke huis, op 'n wyse wat versoenbaar is met demokrasie. ${ }^{116}$

Volgens Swart ${ }^{117}$ is hierdie bepalings spesifiek daarop gemik om die waardes wat in artikel 1(d) verskans word te laat realiseer en om te verseker dat die Parlement as openbare forum funksioneer vir die doel waarvoor dit daargestel is. Verder kan hierdie waardes van verantwoordbaarheid, deelnemendheid en openheid tog nie bevredig word

111 A 42(3) en 42(4) tov die Nasionale Raad van Provinsies.

112 A 59(1)(a) en 72(1)(a).

113 A 59(1)(a) en 72(1)(b).

114 A 59(2).

115 A 57(1)(b) en 70(1)(b).

116 A 57(2)(b) en 70(2)(c).

117 Swart 1996 SAPR 463. 
indien die wetgewende gesag van die Parlement aan die uitvoerende gesag gedelegeer sou word om dit by wyse van regulasies, proklamasies en goewermentskennisgewings uit te oefen nie. Die prosedure by die uitreik van hierdie instrumente van ondergeskikte wetgewing voldoen bloot nie aan dieselfde mate van openheid en deelnemende demokrasie as wat die geval is met sake wat deur die Parlement op sy agenda geneem word volgens die "manner and form"-bepalings van artikels 75, 76 en 77 nie, selfs al word dit toeganklik gemaak vir die publiek ingevolge artikel 101(3), of in die Parlement ter tafel gelê ingevolge artikel 17 van die Interpretasiewet. ${ }^{118}$

Hierdie wet bly 'n gewone wet van die Parlement wat te eniger tyd herroep kan word en ondergeskikte wetgewing bly instrumente wat net toeganklik moet wees vir die publiek en op 'n wyse gemaak moet word soos dit in wetgewing bepaal word. Dit sal nie noodwendig in lyn met die bepalings van artikel 75, 76 en 77 wees nie. Wette van die Parlement daarenteen moet deur die President onderteken en spoedig gepubliseer word, sodat dit gepromulgeer kan word deur publikasie of op 'n datum in die betrokke wet bepaal. Ook hierdie publikasievereiste help om die waarde van openheid te laat realiseer. Dit is egter nie noodwendig 'n grondwetlike vereiste by ondergeskikte wetgewing nie. Indien wetgewende gesag van die Parlement op so 'n wyse deur die uitvoerende gesag hanteer sal word, sal die waardes in artikel 1(d) ongetwyfeld agterweë bly, sowel as die verpligte "manner and form"-vereistes, iets wat nie mag of kan geskied nie. Woolman stel dit dalk die beste: ${ }^{119}$

Only when people know what [Parliament] is doing and why can they offer their consent. Only when the citizens offer willingly and knowingly their consent to the state's actions can the state be deemed legitimate.

Die gevolgtrekking ten aansien van die "manner and form"-bepalings, soos dit in die Western Cape Legislature-saak beslis is, is verder in lyn met die Grondwetlike Beginsels waaraan die Grondwet moes voldoen om deur die Konstitusionele Hof gesertifiseer te

118 Interpretasiewet 33 van 1957.

119 Woolman 1996 SAJHR 124. 
kon word. ${ }^{120}$ Grondwetlike Beginsel VI bepaal dat daar 'n verdeling tussen die magte van die wetgewende, uitvoerende en regsprekende gesag moes wees, met gepaste wigte en teenwigte ten einde verantwoording, verantwoordbaarheid en openheid te verseker. Dit gaan saam met Grondwetlike Beginsel X wat bepaal het dat formele wetgewende prosesse deur wetgewende organe op alle vlakke nagekom moet word. Hieruit blyk dit dus waarom die waardes van artikel 1 in die Grondwet voorkom sowel as die skeiding van magte ${ }^{121}$ en die "manner and form"-bepalings van artikels 75, 76 en 77, wat die vereiste van Grondwetlike Beginsel X moes bevredig. ${ }^{122}$

Hierdie argument word verder bevestig indien ons die onlangse beslissing van Roman $v$ Williams $^{123}$ in die Kaapse Provinsiale Afdeling in oënskou sou neem. In dié gewysde het die hof tot die noodwendige gevolgtrekking gekom dat die rol van die howe by die hersiening van administratiewe besluite nie meer net beperk is tot die wyse waarop dit bereik is nie, maar ook nou die inhoud en meriete van die besluit kan toets. Dit moet immers so wees indien ons artikel 33 van die Grondwet daadwerklike aanwending wil laat vind. Omdat ondergeskikte wetgewing egter nie uitgevaardig word met dieselfde prosedurele en "manner and form"-vereistes as wat by wetgewing die geval is nie, kan dit gestel word dat die uitvoerende gesag se uitvaardiging van hierdie ondergeskikte wetgewing getoets sal kan word, ook ten opsigte van die inhoud daarvan.

Dit is egter reeds baie lank 'n reël dat die howe nie politieke beleidsbesluite kan toets nie, ${ }^{124}$ soos wat die geval is vanuit die Britse tradisie. ${ }^{125}$ Nou sal die howe dit wel uit hoofde van artikel 33 en Roman $v$ Williams ${ }^{126}$ kan doen indien wetgewende gesag gedelegeer kan word, omdat die inhoud en meriete van administratiewe besluite ook onderhewig is aan die howe se toetsingskompetensie. Dit kan tog nie, want dan gaan die

120 Swart 1996 SAPR 464.

121 Hfst 4, 5 en 8 van die Grondwet.

122 Die Grondwetlike Beginsels mag gebruik word as 'n hulpmiddel om die Grondwet uit te lê. Daar is reeds in die inougurele uitspraak van die Konstitusionele Hof, $S v$ Makwanyane 19956 BCLR 665 (KH) op 676H-I, 678G-H en 679D-680E 'n beslissing gemaak aangaande die rol wat die geskiedenis en die agtergrond tot die Grondwet in die uitleg daarvan mag speel.

123 Roman $v$ Williams 19981 SA 270 (K).

124 Wiechers Administratiefreg 334-335.

125 Yardley British Law 124. 
skeiding van magte tussen wetgewende en regsprekende gesag weer verlore, wat sal beteken dat hierdie gesag bloot nie aan die uitvoerende gesag gedelegeer sal kan word nie. Om aan te voer dat Roman $v$ Williams ${ }^{127}$ verkeerd is, sou weer die werking van artikel 33 ondermyn. Alhoewel die uitvaardig van ondergeskikte wetgewing as administratiefregtelik aangemerk kan word, deur dit byvoorbeeld te klassifiseer as ministeriële handelinge, ${ }^{128}$ is dit nie die doel van hierdie artikel om hierop in te gaan nie. Die verwysing na Roman $v$ Williams ${ }^{129}$ en die bespreking daarvan is bloot om die argumente ten gunste van die "manner and form"-vereistes te bevestig, soos dit in ons reg vereis word om die waardes in artikel 1(d) van die Grondwet te laat neerslag vind.

Swart ${ }^{130}$ se laaste argument om die grootliks onbeperkte delegasie van wetgewende gesag aan die uitvoerende gesag te voorkom, het spesifiek te make met die hef van belastings ingevolge die Inkomstebelastingwet 58 van 1962, soos die wet tans daar uitsien. Hierdie argument handel oor die geheimhoudingsbepalings ingevolge dié betrokke wet, sowel as ander belastingwette wat byvoorbeeld 'n verbod op alle persone plaas om enige inligting te publiseer wat betrekking het op die belastingsake van 'n belastingbetaler of 'n klas belastingbetalers. ${ }^{131}$ Dit sal ook inligting insluit oor die wyse waarop gedelegeerde wetgewende gesag uitgeoefen is deur 'n belastingkommissaris met betrekking tot die geval van 'n individuele belastingbetaler of klas belastingbetalers. Dié geheimhoudingsbepalings sal dit vir individuele belastingbetalers moeilik maak om uit te vind of daardie kommissaris sy gesag arbitrêr uitgeoefen het ten opsigte van die betrokke belastingbetaler. Daardie belastingbetaler se reg op gelyke behandeling voor die reg ${ }^{132}$ kon aangetas gewees het.

Argumente sal daarvoor uitgemaak kan word dat die belastingbetaler se regte in die Grondwet van toepassing is ten opsigte van toeganklikheid tot die kommissaris se

126 Roman $v$ Williams 19981 SA 270 (K) op 281.

127 Roman $v$ Williams 19981 SA $270(\mathrm{~K})$.

128 Yardley British Law 122.

129 Roman $v$ Williams 19981 SA $270(\mathrm{~K})$.

130 Swart 1996 SAPR 467.

131 A 4(2A) van die Inkomstebelastingwet 58 van 1962 soos gewysig. Hierdie inligting mag egter deur die betrokke belatingbetaler self, of sy verteenwoordiger bekendgemaak of gepubliseer word. 
belastingramings wat hy ten opsigte van die individuele belastingbetaler of 'n klas belastingbetalers gemaak het, as ondergeskikte wetgewing. ${ }^{133}$ Daar sal verder aangevoer kan word dat die reg op inligting ook van toepassing sou wees op daardie ramings ${ }^{134}$ en dat dit die geheimhoudingsbepalings in daardie belastingwette kan oorskry. Dit kan egter steeds moeilik wees om vas te stel of die praktyke wat aan die belastingbetaler geopenbaar word deur die kommissaris op 'n gelyke wyse toegepas word ten opsigte van alle belastingbetalers of klasse van belastingbetalers, omdat die geheimhoudingsbepalings dit moeilik kan maak om hierdie persone of klasse te kan identifiseer. ${ }^{135}$

'n Uitvoerende omgewing waarin geheimhouding ondersteun en in stand gehou word, is 'n teelaarde vir arbitrêre optrede, veral waar dit moeilik is om daarteen op te tree. Hierdie geheimhoudingsbepalings kan moontlik regverdigbaar wees ingevolge artikel 36 van die Grondwet wat oor die beperking van regte handel. Gevolglik sal dit onwys wees om, vanuit 'n beleidsoogpunt, volkome wetgewende gesag te delegeer aan 'n uitvoerende orgaan wat onderhewig is aan 'n plig om geheimhouding in stand te hou. ${ }^{136}$

Laastens moet die kwessie van die beperking van regte aangeroer word. In die Grondwet word spesifiek hiervoor voorsiening gemaak ingevolge artikel 36 wat spesifieke kriteria neerlê wat in ag geneem moet word ten einde te bepaal of die beperking die toets van grondwetlikheid slaag, al dan nie. In 'n demokratiese gemeenskap kan die uitvoerende gesag die fundamentele regte beperk slegs wanneer dit so gemagtig word deur die wetgewer. Hoe groter die inbreuk op die fundamentele regte van die individu, hoe groter is die behoefte vir wetgewende magtiging. Die sogenaamde Rechtsstaat-beginsel vereis dat wette die uitvoerende gesag se kompetensies duidelik moet afbaken. In die slegste

132 A 9(1) van die Grondwet.

133 A 101(3) van die Grondwet.

134 A 32 van die Grondwet.

135 A 32(1)(b) sou moontlik aangewend kon word om ander belastingbetalers wat in 'n soortgelyke posisie is te dwing om die betrokke belastingbetaler van inligting te voorsien oor die wyse waarop die kommissaris enige van sy gedelegeerde gesag uitgeoefen het ten opsigte van hulle indien die betrokke belastingbetaler hierdie inligting sou benodig vir die uitoefening of beskerming van enige van sy regte. Dit mag egter beperk word deur a 32(2) in nasionale wetgewing. Sien ook item 23(2)(a) en (3) van Bylae 6. 
scenario moet vae regsterme eerder deur die howe uitgelê word as deur die uitvoerende gesag self. Die uitvoerende gesag kan egter die diskresie verleen word om self te besluit of dit sy gesag wil uitoefen of nie. Sodanige diskresie is byvoorbeeld in die Duitse reg bevind om wel die grondwetlike toets te slaag, omdat dit die individu van onnodige inmenging deur die uitvoerende gesag beskerm. ${ }^{137}$ Soos in die Duitse reg meen Rautenbach en Malherbe ${ }^{138}$ dat die Parlement wel 'n diskresie aan die uitvoerende organe sal kan delegeer om regte te beperk, maar dit sal aan die vereistes van artikel 36 moet voldoen en die gesag om regte te beperk kan nie geheel en al aan so 'n orgaan oorgedra word nie.

Die grondslag van die reëling dat regte slegs kragtens algemeen geldende reg beperk mag word, is dat die wetgewer as verteenwoordiger van die kiesers, die beginselbesluite daaroor moet neem en niemand anders nie. ${ }^{139}$

Artikel 36 verskans hierdie beginsel. Die skrywers regverdig hul argument uit hoofde daarvan dat ' $\mathrm{n}$ totale oordrag van die gesag om regte te beperk, nie eens in artikel 37 ten opsigte van noodtoestande in die vooruitsig gestel is nie. Wetgewing na aanleiding van 'n verklaring van 'n noodtoestand mag slegs van die Handves van Regte afwyk in die mate wat die afwyking streng deur die noodgeval vereis word. ${ }^{140}$ Sowel die verklaring en verlening van die noodtoestand as enige wetgewing of stappe ingevolge die verklaring word gekontroleer deur die wetgewer en die howe. ${ }^{141}$

Uiteindelik kan daar baie argumente aangevoer word om aan te toon dat die delegasie van die wetgewende gesag van die Parlement aan die uitvoerende gesag ongrondwetlik en gevolglik ontoelaatbaar is, maar een bly die deurslaggewendste: Suid-Afrika is sedert 27 April 1994 'n demokratiese regstaat.

136 Swart 1996 SAPR 467.

137 Davis, Chaskalson en De Waal Democracy and Constitutionalism 95.

138 Rautenbach en Malherbe Staatsreg 205.

139 Rautenbach en Malherbe Staatsreg 205.

140 A 37(4)(a). 


\section{$5 \quad$ Gevolgtrekking}

Dit blyk dat die Suid-Afrikaanse reg neig om die Duitse benadering ten opsigte van die delegasie van wetgewende gesag na te volg. Dit volg daaruit dat die Konstitusionele Hof die blote delegasie van essensiële wetgewende gesag as ontoelaatbaar beskou. ${ }^{142}$ Perke moet geplaas word op die omvang van die Parlement se delegasiebevoegdheid en die "manner and form"-vereistes moet nagekom word by die skep van wetgewing. Dit gebeur nie in gevalle van essensiële wetgewende delegasies aan die uitvoerende gesag nie. Indien essensiële wetgewende gesag wel aan die uitvoerende gesag gedelegeer word, dan word dit uitgeoefen by wyse van ondergeskikte wetgewing, en laasgenoemde geniet in elk geval dieselfde regskrag as wetgewing van die Parlement.

Na oorweging van die Duitse regsposisie is die posisie ingevolge die Oorgangsgrondwet onder die loep geneem met die bespreking van enkele hofuitsprake ${ }^{143}$ wat lig op die onderwerp verskaf het, waarna die argumente aangevoer is waarom die posisie soortgelyk daar behoort uit te sien na die inwerkingtrede van die finale Grondwet. Die rede hiervoor is dat beide sake wat in die Konstitusionele Hof oor die kwessie beslis is, ingevolge die Oorgangsgrondwet voor daardie hof gedien het. Uiteindelik sal daar baie moeilik tot 'n ander gevolgtrekking gekom kan word as dat die delegasie van wetgewende gesag aan die uitvoerende gesag nie kan geskied op 'n baie wye grondslag sonder perke nie. Die delegasie van die gesag om wetgewing te herroep, te wysig of byvoorbeeld belasting te hef, sal ontoelaatbaar wees. Magtigende wetgewing wat enige wetgewende gesag sou delegeer, moet riglyne neerlê. Hierdie riglyne moet dan minstens handel oor hoe die gesag wat gedelegeer word ten aansien van die ondergeskikte wetgewing wat ingevolge daarvan uitgevaardig moet word, uitgeoefen moet word. Magtiging tot delegasie mag natuurlik steeds nie oor sake handel wat as essensieel

141 A 37(3).

142 Executive Council, Western Cape Legislature v President of RSA 19954 SA 877 (KH) by par 62.

143 Ynuico Ltd v Minister of Trade and Industry 19966 BCLR 798 (KH) en Executive Council, Western Cape Legislature $v$ President of RSA 19954 SA 877 (KH). 
beskou sou kon word nie. Bepalings word voorts vereis ten opsigte van kriteria wat daarop van toepassing sal wees om dit te kan doen. ${ }^{144}$

Dit wil dus voorkom dat ons eie Konstitusionele Hof dieselfde lyn van argumentering volg as die Duitse Konstitusionele Hof (Bundesverfassungsgericht), en dit na alle verwagting ook behoort te doen by die beperking van regte. Soos die Duitse Konstitusionele Hof wil dit voorkom dat die Suid-Afrikaanse Konstitusionele Hof die volgende vereis: magtigende wetgewing moet die inhoud, omvang en doel van die magtigende bepalings neerlê, voordat die ondergeskikte wetgewing gelding kan geniet. Hierdie inhoud, omvang en doel van die ondergeskikte wetgewing sal nie vir die eerste keer in die ondergeskikte wetgewing kan voorkom nie, maar moet in die magtigende bepalings vervat wees. Indien dit nie die geval is nie, sal dit immers daarop neerkom dat die wetgewende gesag daardie gesag tot 'n ongrondwetlike mate aan die uitvoerende gesag oorgedra het en sal die probleme aangaande die omseiling van byvoorbeeld die "manner and form"-vereistes ter sprake kom, soos dit hierbo bespreek is. Dit sal op sy beurt weer lei tot die omseiling van byvoorbeeld die waardes wat in artikel 1(d) van die Grondwet vervat is, wat verdere ongrondwetlikheid sal teweegbring. Verder is dit 'n feit dat die leerstuk van die skeiding van magte baie sterk aanwending behoort te vind in die Suid-Afrikaanse staatsreg weens die breuk wat daar met die verlede gemaak is in 1994. Indien die uitvoerende gesag met essensiële wetgewende gesag opgesaal word, kan dit tot 'n ondermyning van die skeiding van magte, soos dit in die Suid-Afrikaanse reg neerslag vind, lei.

Dit bring ons tot die uiteindelike gevolgtrekking: 'n Wye delegasie van wetgewende gesag aan die uitvoerende gesag, sonder perke vir die uitoefening daarvan, byvoorbeeld ten opsigte van inhoud, omvang en doel, is sonder twyfel, ongrondwetlik.

144 Per Chaskalson Executive Council, Western Cape Legislature v President of RSA 19954 SA 877 (KH) Par 137 931J, par 141 933F-G en par 209 958H. 


\section{BIBLIOGRAFIE}

Baxter Administrative Law

Baxter L Administrative Law (Juta Kaapstad 1984)

Chaskalson Constitutional Law

Chaskalson M ea (reds) Constitutional Law of South Africa (Kenwyn 1996)

Crowther en Hornby Current English

Crowther J en Hornby AS (reds) Oxford Advanced Learner's Dictionary of Current English 5e uitg (Claredon Press Oxford 1995)

Davis Chaskalson en De Waal Democracy and Constitutionalism 95

Davis D Chaskalson M en De Waal J "Democracy and Constitutionalism: The Role of Constitutional Interpretation" in Van Wyk D (red) Rights and Constitutionalism: The New South African Legal Order (Juta Kenwyn 1994) 95

De Ville 1993 SAPR

De Ville J "Die Legaliteitsbeginsel in die Staats-en Administratiefreg onder 'n Nuwe Grondwetlike Bedeling - 'n Vergelykende Toekomsperspektief" 1993 SAPR 68-85

Devenish Commentary

Devenish GE A Commentary on the South African Constitution (Butterworth Durban 1998)

Henning Diskresie in Administratiefreg

Henning PJ van R Oor die Begrip Diskresie in die Suid-Afrikaanse Administratiefreg (LLD-Proefskrif PU vir CHO 1967) 


\section{Hewitt Delegated Legislation}

Hewitt DJ The control of delegated legislation, being a study of the doctrine of ultra vires in relation to the legislative powers of the executive government, with special reference to Great Britain, Australia, New Zealand and Canada (Butterworth Sydney 1953)

Hiemstra en Gonin Regswoordeboek

Hiemstra VG en Gonin HL Drietalige Regswoordeboek Engels-Afrikaans, LatynAfrikaans-Engels, Afrikaans-Engels 3e uitg (Juta Kaapstad 1992)

Keir en Lawson Constitutional Law

Keir DL en Lawson FH Cases on Constitutional Law (Claredon Press Oxford 1954)

Makins English Dictionary

Makins M ea (red) Collins English Dictionary 3e uitg (Longman Glasgow 1991)

Malherbe 1996 TSAR

Malherbe EFJ "Grondwetlike Oppergesag in Werking Executive Council, Western Cape Legislature v President of RSA 199510 BCLR 1289 (KH)" 1996 TSAR 175182

Odendal ea Handwoordeboek

Odendal FF ea (reds) HAT: Verklarende Handwoordeboek van die Afrikaanse Taal 3e hers uitg (Perskor Midrand 1994)

Rabie en Erasmus 1989 SALJ

Rabie A en Erasmus G "When Delegated Powers Become Plenary Powers" 1989 SALJ 440-449

Rautenbach en Malherbe Staatsreg Rautenbach IM en Malherbe EFJ Staatsreg 2e uitg (Butterworth Durban 1996) 
Singh German Administrative Law

Singh MP German Administrative Law in Common Law Perspective (Springer Berlyn 1985)

Swart 1996 SAPR

Swart GJ "Constitutional Limitations on the Delegation of Powers of Taxation" 1996 SAPR 446-471

Tribe American Law

Tribe LH American Constitutional Law 2e uitg (NY Foundation Press Mineola 1988)

Wiechers Administratiefreg

Wiechers M Administratiefreg 2e uitg (Butterworth Durban 1984)

Woolman 1996 SAJHR

Woolman S "Coetzee: The limitations of Justice Sachs's concurrence" 1996 SAJHR 99

Yardley British Law

Yardley DCM Introduction to British Constitutional Law 6e uitg (Butterworth Londen 1984)

\section{Register van Regspraak}

Executive Council, Western Cape Legislature v President of the Repucblic of South Africa and others 19954 SA $877(\mathrm{KH})$

In re: Certification of the Constitution of the Republic of South Africa 1996199610 BCLR $1253(\mathrm{KH})$

Kendall v United States ex rel. Stokes 37 US (12 Pet) 524 (1838)

Kilbourn v Thompson 103 US 168191 (1881) 
Roman v Williams NO 19981 SA 270 (K)

$S \vee$ Coetzee 70/92 ['n Ongerapporteerde beslissing in die Witwatersrandse plaaslike afdeling op 28 September 1995]

S v Makwanyane 19956 BCLR $665(\mathrm{KH})$

Shidiack v Union Government (Minister of the Interior) 1912 AD 642

Ynuico Ltd v Minister of Trade and Industry 1996 (6) BCLR 798 (KH)

Ynuico Ltd v Minister of Trade and Industry and Others 1995 (11) BCLR 1453 (T)

1 BVerfGE 14

5 BVerfGE 71

7 BVerfGE 282

8 BVerfGE 71

9 BVerfGE 137

14 BVerfGE 174

14 BVerfGE 245

20 BVerfGE 57

20 BVerfGE 150

33 BVerfGE 1

34 BVerfGE 165

34 BVerfGE 52

40 BVerfGE 237

49 BVerfGE 89

54 BVerfGE 143

55 BVerfGE 207

58 BVerfGE 257

\section{Register van Wetgewing}

Grondwet van die Republiek van Suid-Afrika 108 van 1996

Grondwet van die Republiek van Suid-Afrika 200 van 1993

Grundgesetz für die Bundesrepublik Deutschland

Inkomstebelastingwet 58 van 1962 
Interpretasiewet 33 van 1957

Oorgangswet op Plaaslike Regering 209 van 1993

Prokl R58 Staatskoerant 164697 Junie 1995

Prokl R59 Staatskoerant 164788 Junie 1995

Wet op Arbeidsverhoudinge 66 van 1995

Wet op die beheer van In- en Uitvoere 45 van 1963

GK R2582 Staatskoerant 1163023 Desember 1988 